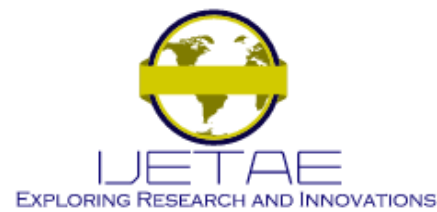

International Journal of Emerging Technology and Advanced Engineering

Website: www.ijetae.com (E-ISSN 2250-2459, Scopus Indexed, ISO 9001:2008 Certified Journal, Volume 11, Issue 05, May 2021)

Manuscript Received: 22 April 2021, Received in Revised form: 16 May 2021, Accepted: 20 May 2021 DOI: 10.46338/ijetae0521_07

\title{
Student Opinions Regarding Microsoft Teams App Used as an Educational Online Learning Environment During Pandemic Process
}

\author{
Ezgi Pelin YILDIZ \\ Kafkas University Kazım Karabekir Vocational School of Technical Sciences Department of Computer Programming KARS \\ TURKEY.
}

\begin{abstract}
With the emergence of smart phone applications and the continuous widespread use of the internet, Learning Management Systems have been used as educational online learning environment. Learning management systems have gained an important position worldwide as an e-learning system in different education institutions with the Covid-19 pandemic since 2020. These educational institutions include higher education. In this process, higher education institutions in continue to frequently use learning management systems such as Moodle, Blackboard, Zoom, Microsoft Teams, Google Meet, and Adobe Connect, Canvas, Advancity. In this context, it is important to evaluate these learning management systems, which are used with the transition to distance education during the pandemic process, in terms of different criteria. This context, in this study it is aimed to evaluate the Microsoft Teams app used within the scope of distance education by students in terms of different criteria. The study is an example of a case study within the scope of qualitative research. The study group of the research consists of 15 students studying at Vocational School of Technical Sciences in university. The opinions of the students about the app were taken through the interview form prepared by the researcher. As a result, when the opinions of the students are evaluated in general, they found the app effective in terms of student-student, studentteacher two-way interaction and also it has been demonstrated that they have problems with some technical issues.
\end{abstract}

Keywords - Student Opinion, Microsoft Teams App, Online Learning Environment, Pandemic Process.

\section{INTRODUCTION}

The COVID-19 pandemic, which caused an unprecedented disruption in education all over the world, disrupted education and training in schools. In this process, while some countries have completely closed down, some have partially closed. As a result, this process affected nearly 2 billion students studying at different levels around the world. Leave was given to schools with the start of the outbreak in Turkey, and then began to distance education.
The Council of Higher Education in Turkey decided to continue higher education completely open and remotely as of spring 2020. After April 6, all universities transitioned to online education to their capacity. With this transition, distance education in higher education has come to the fore completely and education has gained great importance with massive open online courses (MOOC).

It is has aimed to use synchronous (synchronous) classroom tools and especially Learning Management Systems for distance education during the pandemic process. In this context, Learning Management Systems (LMS) are web software used to perform distance education activities.

Often called an LMS for short, a learning management system is a software application that provides the framework that handles all aspects of the learning process - it's where house, deliver, and track your training content. While most often called an LMS, other names that might be used is training management system, learning activity management system or even learning experience platform (LEP). Although there are many tools in the LMS class, open source Microsoft Teams app draws attention with its advantages such as being easy to use, having a single user interface and video conference support (Turnbull, Chug \& Luck, 2019).

When the features of Microsoft Teams app are examined (https://www.microsoft.com/tr-tr/education/products/teams):

- group chat, video calling,

- real-time access, sharing and co-authoring,

- $\quad$ lanning by keeping notes, documents and calendar together,

- $\quad$ creating team, live meeting and communication with two or 10,000 people,

- make calls directly to Microsoft Teams with advanced features like group calling, cloud voicemail, and call transfers, 


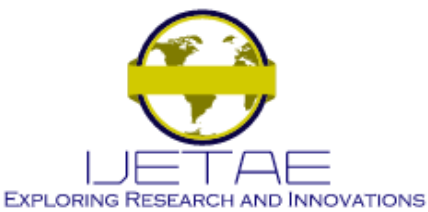

International Journal of Emerging Technology and Advanced Engineering Website: www.ijetae.com (E-ISSN 2250-2459, Scopus Indexed, ISO 9001:2008 Certified Journal, Volume 11, Issue 05, May 2021)

- using applications such as Word, PowerPoint and Excel in Microsoft Teams to find, share and edit in real time with files.

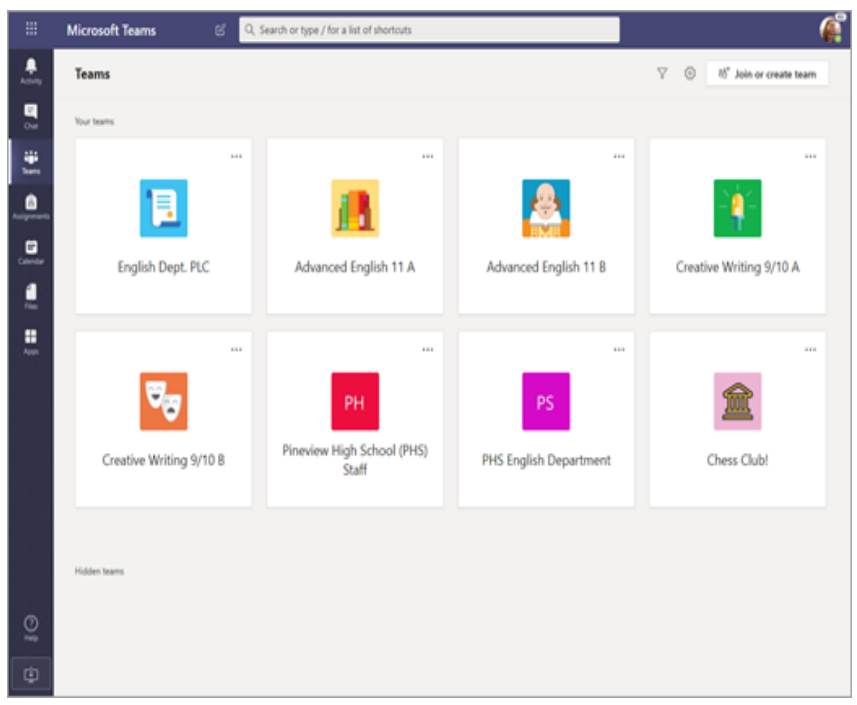

Figure 1. Microsoft Teams Interface and Creating Course Content

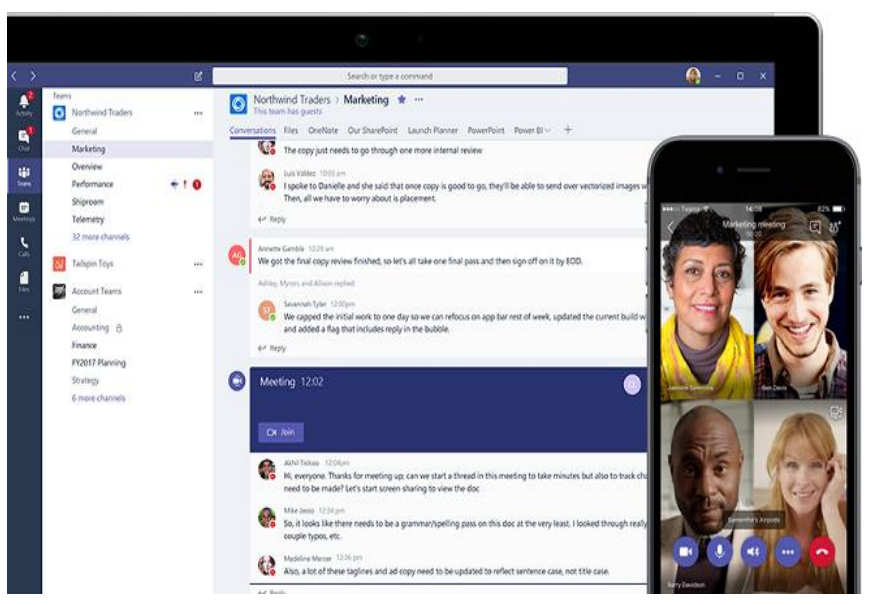

Figure 2. Microsoft Teams' Communication Page

When the studies in the literature on Microsoft Teams are examined; Khomik et al. (2021), examined Microsoft Teams and Moodle platforms in e-learning for disabled students studying at Higher Education Institutions in Ukraine. Adaptive physical education lesson was included in the process. As a result, the main peculiarities and advantages of the distance learning course Adaptive Physical Education are described created in the Moodle system. The differences and benefits of Microsoft Teams over the Moodle platform in the process of e-learning for students with disabilities are described. In the research, a questionnaire that measures the main difficulties of students with disabilities was developed as a data collection tool. In this survey, disabled students stated that they found Microsoft Teams and Moodle platforms very useful within the scope of the relevant course and that other course applications they were deprived of due to physical disabilities can also offer to them through these platforms.

Catherall \& Limniou (2021) they have conducted a series of online seminars within a Cyberpsychology module to explore the psychological and social impact of computers, digital technology and virtual environments at the University of Liverpool (UoL) School of Psychology. Seminar coverage included issues of identity and role of individuals in virtual communities, problematic uses of the Internet and cybersecurity. The module duration was 12 weeks with online seminars delivered via Microsoft Teams and the Blackboard Virtual Learning Environment (VLE), ensuring inclusive access for remote participants. As a result the cyber security seminar, conducted on Microsoft Teams and the Blackboard platform, received positive reviews in terms of curriculum planning.

\section{I.I. The Purpose of the Research}

The main purpose of this research is to determine the use of Microsoft Teams app, which is frequently preferred in higher education during the pandemic period, as part of a course and to determine students' opinions about this use.

\section{I.I. The Importance of Research}

This study generally sheds light on the use of Microsoft Teams as a learning app during the Covid-19 pandemic process. It is also intended to check whether students are motivated to use Microsoft Teams as a learning app and to test the effectiveness of Microsoft Teams itself as an educational online learning environment during pandemic process. With the answers from these questions, the Microsoft Teams app will be evaluated as an online online learning platform in terms of various criteria and in this context, it will be interpreted with its advantageous and disadvantageous properties. It is expected that all these evaluations, opinions and comments will serve as an example for future studies and researchers and will contribute to the literature in this sense. 


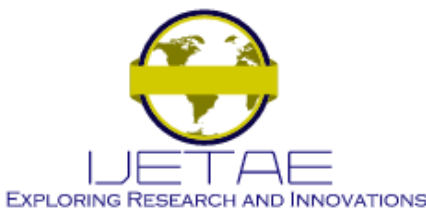

International Journal of Emerging Technology and Advanced Engineering

Website: www.ijetae.com (E-ISSN 2250-2459, Scopus Indexed, ISO 9001:2008 Certified Journal, Volume 11, Issue 05, May 2021)

\section{METHOD}

The study is an example of a case study within the scope of qualitative research. "Case study" is a type of research based on analyzes. A case study is a research method to gain a better understanding of a subject or process. Also case studies involve in-depth research into a given subject, in order to understand it's functionality and successes (George \& Bennett, 2005; Starman, 2013; Creswell, 2017).

General characteristics of case study according to Press Academia, 2018;

- A case study is a research strategy and an empirical inquiry that investigates a phenomenon within its real-life context.

- Case studies are based on an in-depth investigation of a single individual, group or event to explore the causes of underlying principles.

- Case study research can be single or multiple case studies, includes quantitative evidence, relies on multiple sources of evidence and benefits from the prior development of theoritical propositions.

\section{II.I. Study Group}

The study group of the research consists of 15 students studying at Vocational School of Technical Sciences in university. Within the scope of the study, these 15 students took the "Vocational English Course" online over Microsoft Teams app for one semester.

The demographic characteristics of the study group:

- the age of the working group ranges from 21 to 32 ,

- 8 of the students are male and 7 are female,

- participants study in the second grade of a university's Technical Sciences Vocational School, Machine department,

- participants have not previously been trained to use Microsoft Teams app.

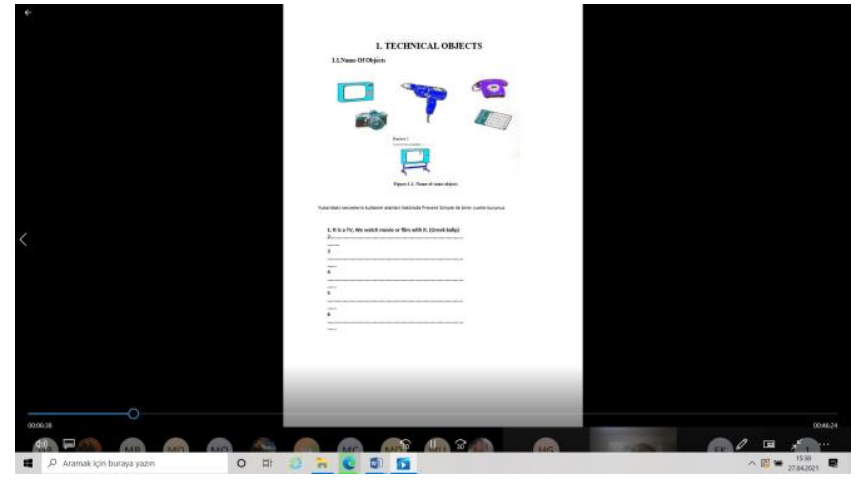

Figure 3. Course content (Vocational English Course) example with Microsoft Teams

\section{II.II. Data Collection Tool and Data Collection Method}

Within the scope of the research, the opinions of the students were taken with the structured interview form developed by the researcher as a data collection tool. Relevant questions were developed with an item pool after a detailed literature review. Expert opinion was consulted after the form was prepared. In this context, expert opinion was received from 3 field experts and 1 linguist expert.

After the necessary corrections were made, the main interview form was obtained. As a result, a student opinion form that served the purpose and consisted of 8 open-ended questions was obtained. The scope of these questions consists of items that evaluate the Microsoft Teams system from various criteria (usefulness, motivation, technical direction etc).

A structured interview form, where participants' confidentiality of information is kept confidential, an environment has been prepared to make them feel comfortable. In this context, volunteerism is taken as a basis.

\section{II.III. Data Analysis}

In the analysis of the data, content analysis was used in accordance with the qualitative research method. Content analysis is first conceptualizing the collected data and then organizing them in a logical way according to the emerging concepts and determining the theme that explains the data at the end of these processes (Buyukozturk, 2018). F (female) and $\mathrm{M}$ (male) letters are used while coding. The reason for this coding is to observe the gender difference. Thus, while reading the comments, metaphors will can be evaluated according to the gender factor. 


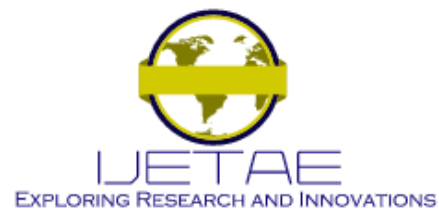

International Journal of Emerging Technology and Advanced Engineering

Website: www.ijetae.com (E-ISSN 2250-2459, Scopus Indexed, ISO 9001:2008 Certified Journal, Volume 11, Issue 05, May 2021)

According to the content analysis, the findings were presented and interpreted. In addition, frequency tables were prepared for the opinions of the students.

\section{FINDINGS AND COMMENTS}

\section{III.I. Questionnaire}

The interview form was developed in order to evaluate the opinions of students about Microsoft Teams App used as an educational online learning environment as part of a course during the pandemic process. 15 students were selected and invited to answer a closed-ended online questionnaire (interview form) via the researcher's email. Yes-no options were used in the questions in the interview form, and the frequency and percentage values were taken during the evaluation phase. In addition, the answers given by the students to open-ended questions were interpreted by the researcher.

\section{Related tables are below:}

Question 1: Do the Microsoft Teams app used for distance education during the pandemic process supply your learning needs?

Table 1. The level of supplying the learning needs of students

\begin{tabular}{|c|c|}
\hline The learning needs & Participants' answers \\
\hline Yes & $80 \%$ \\
\hline No & $20 \%$ \\
\hline
\end{tabular}

Chart 1

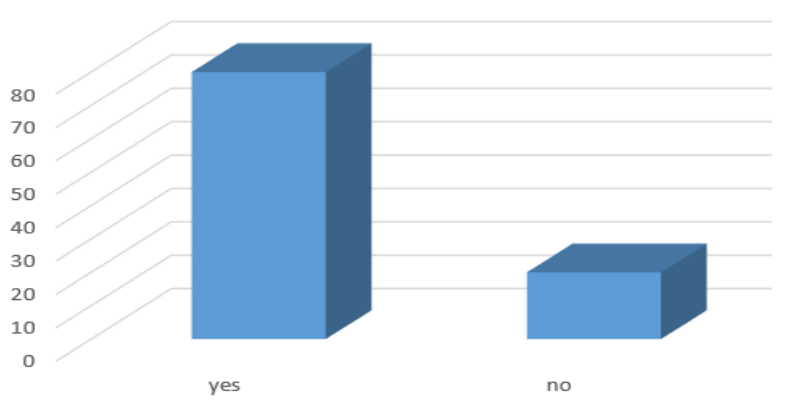

Chart 1 . The rate of supplying the learning needs of students

When the answers given by the students in terms of suppliying their learning needs via Microsoft Teams App are examined; $80 \%$ of students answered yes to this question. This rate constitutes a sufficient percentage. However, 20 percent of the students answered no.
When the answers given by the students to the openended question are evaluated:

\section{M1: My answer is yes;}

In this period when the disease was intense, education activities could continue without interruption, which shows that a very positive process in terms of health has been handled for us students and teachers. In the previous period, we used Moodle LMS for this purpose. But I found Microsoft Teams more advantageous in terms of ease of use and simplicity of access to the course.

F2: My answer is yes;

In this regard, I find the Microsoft Teams app particularly successful in online course management. During these periods when the pandemic is intense, we can easily contact our teachers from our homes and provide access to the lessons via Microsoft Teams app.

\section{M15: My answer is yes;}

In terms of course management, our teachers manage all course materials remotely, such as face-to-face training, very well and efficiently via Microsoft Teams app.

\section{F8: My answer is no;}

I find the management of the process unsuccessful in terms of our applied lessons. We only received theoretical knowledge in these courses. I think no online learning environment/tool can meet this need.

Question II: Do you find the Microsoft Teams app that you used during the pandemic in line with course management and course content presentation useful?

Table 2. Useful in line with course management and course contents

\begin{tabular}{|c|c|}
\hline $\begin{array}{c}\text { Course management } \\
\text { and course content } \\
\text { presentation }\end{array}$ & Participants' answers \\
\hline Yes & $67 \%$ \\
\hline No & $33 \%$ \\
\hline
\end{tabular}




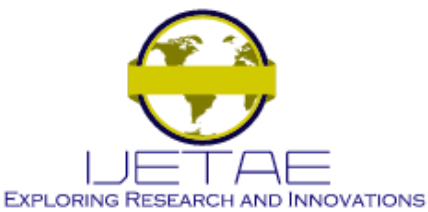

International Journal of Emerging Technology and Advanced Engineering Website: www.ijetae.com (E-ISSN 2250-2459, Scopus Indexed, ISO 9001:2008 Certified Journal, Volume 11, Issue 05, May 2021)

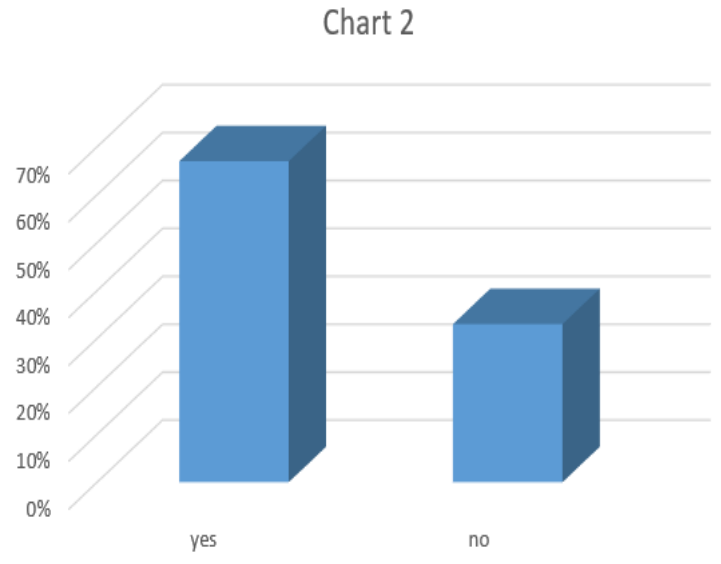

Chart 2. The rate of useful in line with course management and course contents

When the answers given by the students in this question, in which the Microsoft Teams app was evaluated in terms of course management and course content presentation, $67 \%$ of the students found the app successful in this regard, 33 percent found it unsuccessful.

When the answers given by the students to the openended question are evaluated:

\section{F4: My answer is yes;}

I find the Microsoft Teams app successful in terms of these criteria. I find the opportunity to do it again, especially when the records made during the lecture are uploaded to the system at the end of the lecture.

\section{M9: My answer is yes;}

I find course management effective on the Microsoft Teams app with features such as video lecture, synchronous communication, and course recording.

\section{M5: My answer is no;}

I cannot evaluate the platform as completely failing in terms of these criteria but Especially I am having problems uploading homework to the system. This situation negatively affects my exam grade.

\section{F14: My answer is no;}

I hate a feature of this platform in this regard. The students and my friends who are members of the course can kick me out of the course. Therefore, my communication with the course is interrupted, and when I re-enter, I miss the course content and I can't focus.
Question III: Are there any benefits of Microsoft Teams app in terms of student-student, student- two-way interaction interaction within the learning process?

Table 3. Student-student, student-teacher two-way interaction within the learning process

\begin{tabular}{|c|c|}
\hline $\begin{array}{c}\text { Two-way } \\
\text { interaction within the } \\
\text { learning process }\end{array}$ & Participants' answers \\
\hline Yes & $86 \%$ \\
\hline No & $14 \%$ \\
\hline
\end{tabular}

\section{Chart 3}

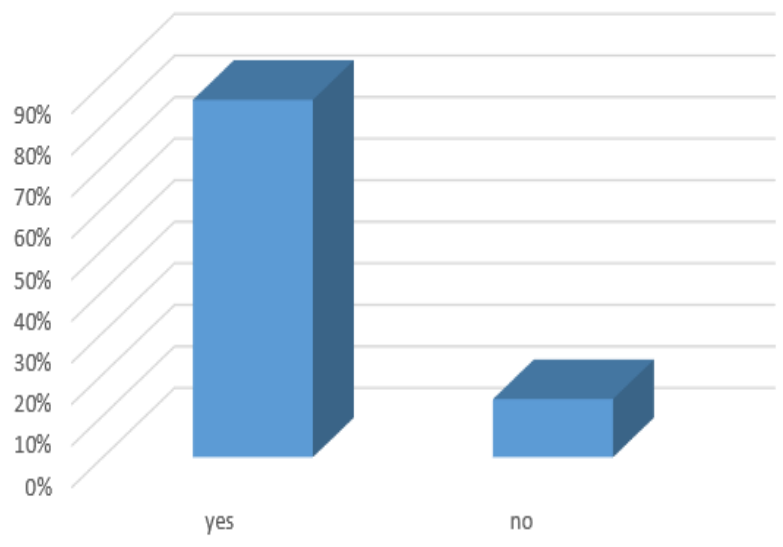

Chart 3. The rate of student-student, student-teacher two-way interaction within the learning process

When the table above is examined, it has been revealed that most of the students are satisfied with the two-way interaction performed via Microsoft Teams.

When the answers given by the students to the openended question are evaluated:

M9: My answer is yes;

I think that our interaction through the Microsoft Teams platform is quite healthy, as is the case with face-to-face training.

M15: My answer is yes;

With the chat module of the Teams platform, I can say what I have to say to my teacher in writing more easily. 


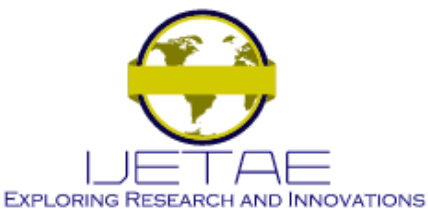

International Journal of Emerging Technology and Advanced Engineering Website: www.ijetae.com (E-ISSN 2250-2459, Scopus Indexed, ISO 9001:2008 Certified Journal, Volume 11, Issue 05, May 2021)

\section{F7: My answer is yes;}

Through the chat module, students - students, students teachers can provide special communication to each other. With the chat module, we can communicate more with each other and our teachers and this situation reflects on our lesson success.

Question IV: Do you find the online exam applications made on the Microsoft Teams app valid and reliable?

Table 4 . The validity and reliability of online exams

\begin{tabular}{|c|c|}
\hline $\begin{array}{c}\text { Microsoft Teams } \\
\text { app technical } \\
\text { challenges }\end{array}$ & Participants' answers \\
\hline Yes & $72 \%$ \\
\hline No & $28 \%$ \\
\hline
\end{tabular}

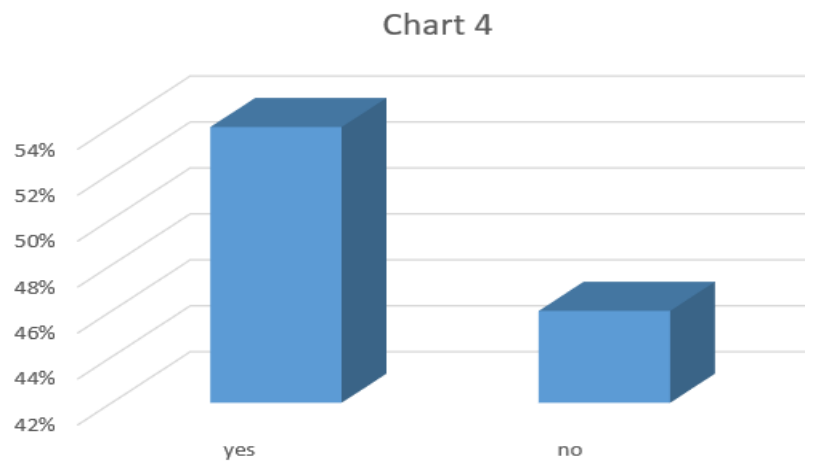

Chart 4 . The rate of validity and reliability of online exams

According to Table 4, when the evaluations of the students for online exams are examined, it is seen that they are undecided.

When the answers given by the students to the openended question are evaluated:

\section{M5: My answer is no;}

Our teachers give the exam time very short, I can give incomplete answers to questions due to time constraints. I do not find online exams valid due to this situation.

\section{F14: My answer is no;}

System fails while answering the questions and we go back to the beginning. This situation causes waste of time.

M6: My answer is yes;
In my opinion, online exams are no different from face-toface exams, our teacher establishes a live connection with us and provides the necessary guidance.

Question V: Do you have technical challenges (course recording, audio system, video course, presentations, live course) in online course conducted on Microsoft Teams app?

Table 5. Microsoft Teams app technical challenges

\begin{tabular}{|c|c|}
\hline $\begin{array}{c}\text { The validity and } \\
\text { reliability of online } \\
\text { exams }\end{array}$ & Participants' answers \\
\hline Yes & $54 \%$ \\
\hline No & $46 \%$ \\
\hline \multicolumn{2}{|c|}{ Chart 5 }
\end{tabular}

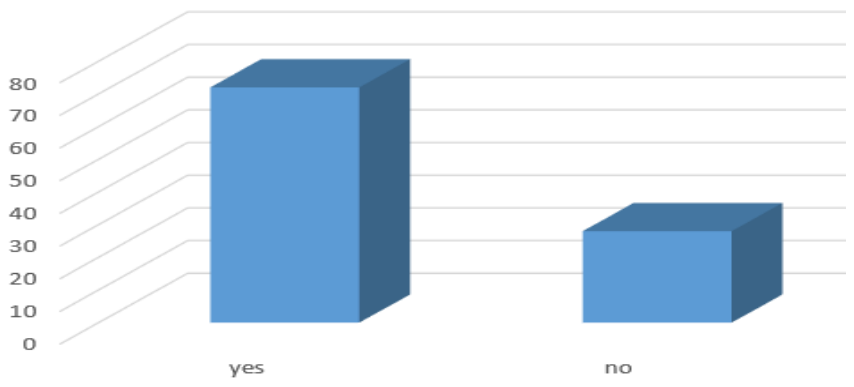

Chart 5. The rate of Microsoft Teams app technical challenges

According to table 5, it is seen that the majority of students do not live technical problems in online courses conducted on the Microsoft Teams app.

When the answers given by the students to the openended question are evaluated:

\section{F12: My answer is no;}

I have never had any problems other than the internet provider. I do not think that this situation, which is caused by the density, causes problems like in the early days of the pandemic.

\section{F7: My answer is no;}

No, I do not live, since this is something related to the internet infrastructure, the fact that my internet infrastructure is at a medium level causes me not to experience these problems. 


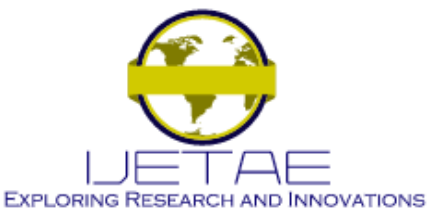

International Journal of Emerging Technology and Advanced Engineering

Website: www.ijetae.com (E-ISSN 2250-2459, Scopus Indexed, ISO 9001:2008 Certified Journal, Volume 11, Issue 05, May 2021)

M10: My answer is yes;

Although I have no problems with my internet provider, the low internet used by my teachers causes interruptions in lecturing

Question VI: Do you think distance learning conducted with the Microsoft Teams app is more effective than traditional classroom teaching?

Table 6. The effectiveness of distance education compared to traditional education

\begin{tabular}{|c|c|}
\hline $\begin{array}{c}\text { Increase } \\
\text { motivation towards } \\
\text { the lessons }\end{array}$ & Participants' answers \\
\hline Yes & $79 \%$ \\
\hline No & $21 \%$ \\
\hline
\end{tabular}

When the student answers are examined in this question, which compares distance education and traditional education, approximately half a ratio is seen.

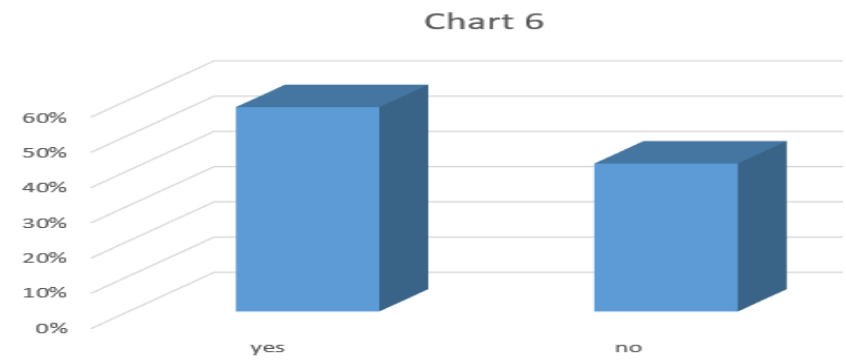

Chart 6. The rate of effectiveness of distance education compared to traditional education

When the answers given by the students to the openended question are evaluated:

F12: My answer is yes;

I saw that I was able to access more useful and more instantaneous information than traditional education. I think I can easily learn what I will learn face to face in the classroom through the Microsoft Times Platform. In addition, I noticed that I can communicate more easily with my teachers online environment. In this context we are more motivated to the lesson by conveying our questions and problems to our teachers.
M10: My answer is no;

I think eye contact is important in teaching. I do not think that teaching is effective since eye contact cannot be established in distance education.

Question VII: Does taking lessons online with the Microsoft Teams app increase your motivation towards the lessons?

Table 7. Taking lessons online with the Microsoft Teams app increase motivation towards the lessons

\begin{tabular}{|c|c|}
\hline $\begin{array}{c}\text { The effectiveness } \\
\text { of distance education }\end{array}$ & Participants' answers \\
\hline Yes & $58 \%$ \\
\hline No & $42 \%$ \\
\hline
\end{tabular}

Chart 7

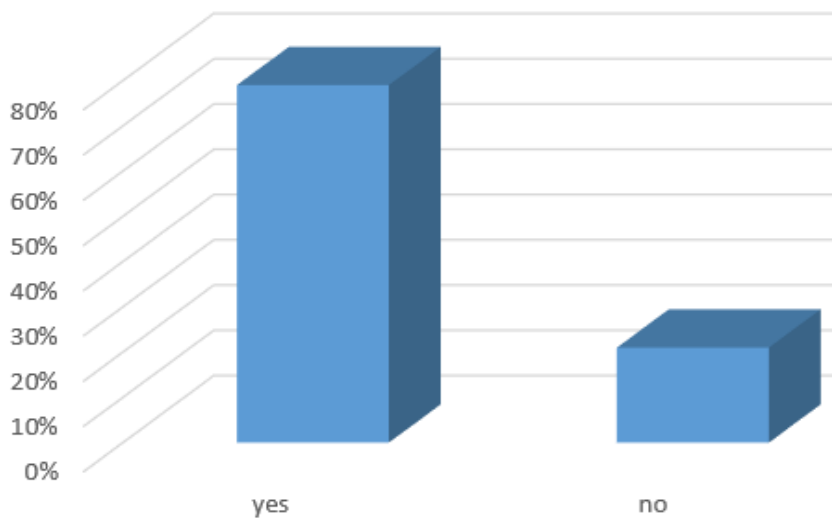

Chart 7. The rate of taking lessons online with the Microsoft Teams app increase motivation towards the lessons

According to the table, students supported the view that taking courses online via Microsoft Teams app increases their motivation towards the course.

When the answers given by the students to the openended question are evaluated:

F14: My answer is yes;

In this context, I can say that I started to research more and use the internet in a healthier way.

F4: My answer is yes; 


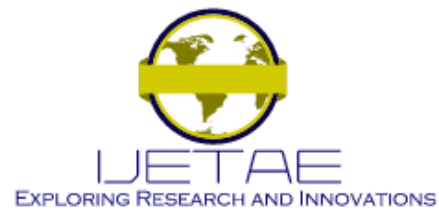

International Journal of Emerging Technology and Advanced Engineering

Website: www.ijetae.com (E-ISSN 2250-2459, Scopus Indexed, ISO 9001:2008 Certified Journal, Volume 11, Issue 05, May 2021)

When I finish my work during the day and come home in the evening, it is nice to have a pleasant time with tea, coffee, etc. and listen to the lessons.

\section{M9: My answer is yes,}

When the online lesson starts, everyone focuses on the teacher's screen and there is no sound so I can concentrate very well.

\section{M5: My answer is no;}

Since I have my parents and siblings at home, I cannot be motivated for the lesson because of the noises coming from them.

Question VIII. If you evaluate the Microsoft Teams platform in general, how many points would you give between 1-10?

Table 8. General Evaluate the Microsoft Teams platform

\begin{tabular}{|c|c|}
\hline $\begin{array}{c}\text { General Evaluate } \\
\text { the Microsoft Teams } \\
\text { platform }\end{array}$ & Participants' points between 1-10 \\
\hline M1 & 8 \\
\hline M3 & 7 \\
\hline M5 & 4 \\
\hline M6 & 4 \\
\hline M9 & 6 \\
\hline M10 & 5 \\
\hline M13 & 6 \\
\hline M15 & 7 \\
\hline F2 & 4 \\
\hline F4 & 7 \\
\hline F7 & 9 \\
\hline F8 & 5 \\
\hline F11 & 8 \\
\hline F12 & 7 \\
\hline F14 & 4 \\
\hline
\end{tabular}

According to the table above, when the evaluation points of the students for the platform are examined, it has been determined that the average is around 6 point. This score is sufficient for the success of Microsoft Teams app.

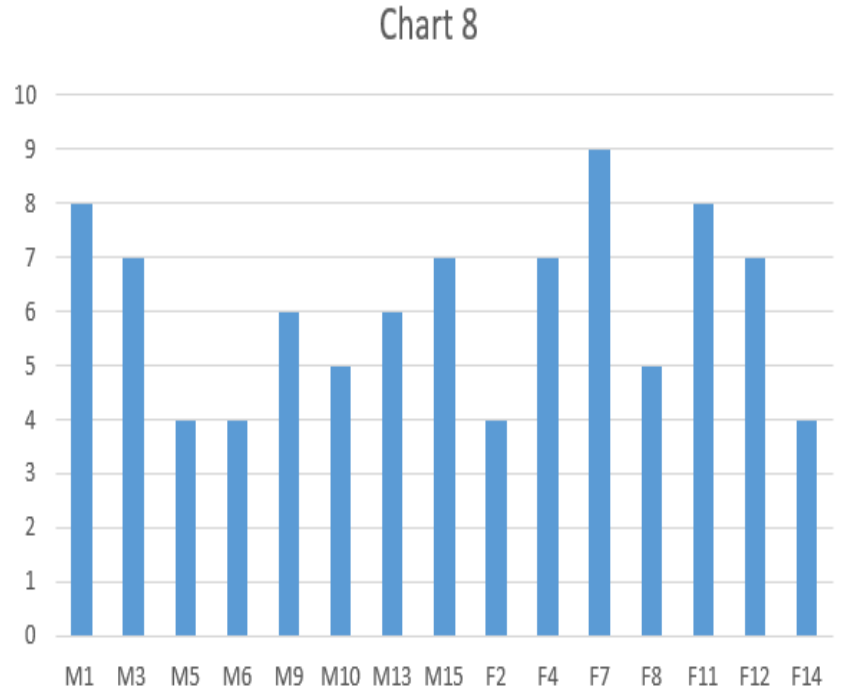

Chart 8. The rate of general evaluate the Microsoft Teams platform

\section{Chart 9. Average}

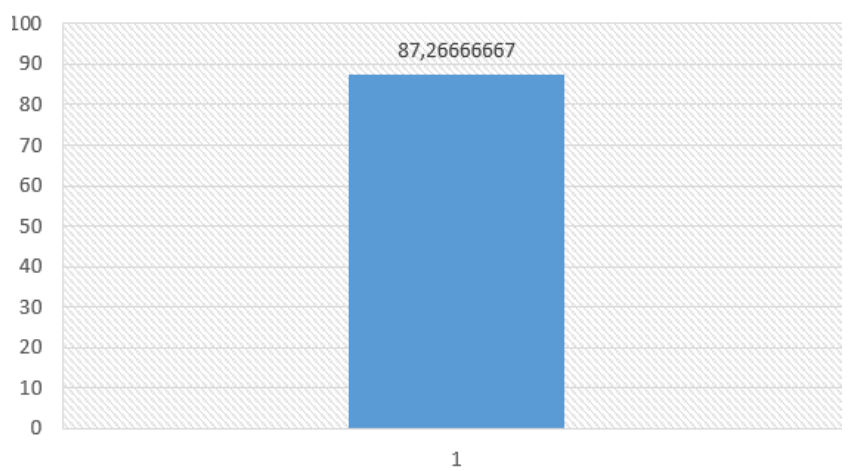

When the answers given by the students to the openended question are evaluated:

F7: When I evaluate the Microsoft Teams app overall, my point is 9 .

First of all, considering the pandemic process in terms of distance and infectious disease risk, such a program has provided great convenience for both academicians and students in such a short time. Except for a few problems (my individual problem: poor quality of the internet provider), I did not live any hitch or negative situations. 


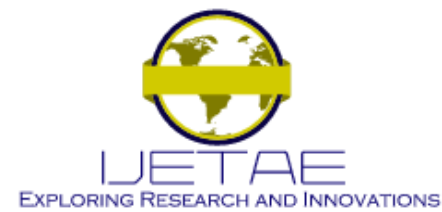

International Journal of Emerging Technology and Advanced Engineering Website: www.ijetae.com (E-ISSN 2250-2459, Scopus Indexed, ISO 9001:2008 Certified Journal, Volume 11, Issue 05, May 2021)

\section{CONCLUSION, DisCUSSION AND RECOMMENDATIONS}

In the last decade, online learning and educational online learning environment has grown rapidly. In this regard, the coronavirus (COVID-19) pandemic has caused learning institutions to adopt online learning (Munster et al. 2020; Hodges et al. 2020; Chinazzi et al. 2020). In recent time the Microsoft Teams app incorporating the Microsoft OneNote becomes increasingly popular and gained users in many fields of work.

This research is a case study in which the Microsoft Teams app, which is used as an educational online learning environment during the pandemic process, is evaluated with the opinions of students. In order to serve this purpose, an interview form was prepared by the researcher. The relevant form consists of 8 open-ended questions that evaluate the Microsoft Teams app in terms of various criteria. When the answers given by the students to these questions were analyzed, it was determined that the Microsoft Teams app was generally found successful as an educational online learning environment.

When the literature is examined, the existence of studies on the evaluation of learning management systems used in the pandemic process draws attention:

Lonescu et al. (2020), they studied the sustainability analysis of the e-learning education system during the pandemic period, and in this context, they discussed the example of Romania. In this research, it is based on an opinion poll based on a questionnaire developed on three levels of schooling (middle school, high school, and university), analyzed from three perspectives, teachersstudents-parents. Research results proved that students accept online learning, although they find it less engaging than traditional teaching. As a general conclusion from the teacher-student-parent perspective, e-learning is an effective sustainable learning solution in present and future conditions.

Kamal et al. (2020), they present a case study on the transition to online learning during COVID-19. In this study, an online questionnaire was developed by the researchers in order to determine the digital migration and the problems experienced by Malaysian students in this context, and this questionnaire was applied to a total of 354 university students. As a result, students found the transition to online education absolutely justified in the Covid 19 pandemic. For further research, it is recommended that this transition be questioned for teachers, academics and all other research communities and evaluate the results.

When the literature is examined, it is possible to meet studies in which other learning management systems platforms are evaluated. Moodle LMS attracts more attention than these studies:

Chourishi et al. (2012), studied on effective e-learning with Moodle in their study. At the end of the research, it was revealed that the possibilities and modules of Moodle are encouraging and motivating in providing effective technology-based learning especially in higher education. Marjan and Igor (2020), they examined the effect of Moodle and Microsoft Teams on teaching-learning-studying (TLS) processes. In the research, both systems were tested for different courses. Moodle has been found more successful in traditional training tasks (assessments, peer-to-peer assessment, exams, categorization, extensibility). MS Teams excels in different types of communication (chatting, video conferencing, lecturing, screen sharing) and general content creation.

As a suggestion for this research;

- Although the students found the Microsoft Teams app generally successful, they mentioned some technical problems (people who are members of the courses have the authority to expel students from the course). In order to solve this problem, the instructors should take the necessary precautions before the course and direct the authority to them completely. Thus, a more effective and uninterrupted course management will be made.

- Most of the students stated that they had time problems in online exams. Instructors should plan their time better in online exams on the platform. This will increase the validity and reliability of the exams.

- With this research, it is aimed to evaluate Microsoft Teams app from a student perspective. Can study with different research groups to allow comparison in future research. 


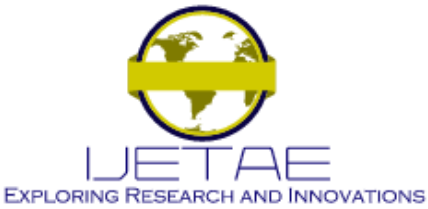

International Journal of Emerging Technology and Advanced Engineering Website: www.ijetae.com (E-ISSN 2250-2459, Scopus Indexed, ISO 9001:2008 Certified Journal, Volume 11, Issue 05, May 2021)

- Since this study is an example of qualitative research, 15 students were determined as a study group. Further studies can be done with more study groups or through a quantitative research method through a questionnaire or scale.

References

[1] Buyukozturk, S. Bilimsel Arastırma Yontemleri. 2018. Pegem Academic Publishing.

[2] Catherall, P. \& Limnio, M. 2021. Providing Library liaison and expertise to support an Online Psychology seminar using Microsoft Teams. Information for Social Change, 39. DOI:10.5281/zenodo.4603306

[3] Chinazzi, M., Davis, J., T., Ajelli, M., Gioannini, C., Litvinova, M., Merler, S. \& Pastor, A. 2020. The effect of travel restrictions on the spread of the 2019 novel coronavirus (COVID-19) outbreak. Science (80-) 368, no. 6489, pp. 395400, doi: 10.1126/science.aba9757, 2020.

[4] Creswell, J. W. 2017. Research design: Qualitative, quantitative, and mixed methods approaches. Thousand Oaks, CA: Sage.

[5] Chourishi, D., Chanchal, D., Buttan, K. \& Chaurasia, A. 2012. Effective E-Learning through Moodle. International Journal of Advance Technology \& Engineering Research. Retrieved from https://www.researchgate.net/publication/265974790_Effective _E-Learning_through_Moodle

[6] George, A., L. \& Bennet, A. 2005. Case Studies and Theory Development in the Social Sciences. Perspectives on Politics 5(1). DOI:10.1017/S1537592707070491

[7] Hodges, C., Moore, S., Lockee, B., Trust, T. \& Bond, A. The difference between emergency remote teaching and online learning. 2020. Educ. Rev., [Online].

[8] Kamal, A. A, Norhunaini, M., S., Truna, L., Sabri, M. \& Junaini, S, N. 2020. Transitioning to Online Learning during COVID-19 Pandemic: Case Study of a Pre-University Centre in Malaysia. International Journal of Advanced Computer Science and Applications 11(6). Retrieved from https://thesai.org/Publications/IJACSA

[9] Khomik, O., Bielikova, N., Indyka, S., Kovalchuk, O., Tomaschuk, O. \& Vlashchuk, V., H. 2021. Accessibility of Microsoft Teams and Moodle Services for the Implementation of E-Learning for Students with Disabilities in Institutions of Higher Education in Ukraine. Technologies of education in physical training 1(53). DOI: https://doi.org/10.29038/22207481-2021-01-33-42
[10] Ionescu, A. C. , Cagetti, M. G. , Ferracane, J. L. , Garcia-Godoy, F. , \& Brambilla, E. 2020. Topographic aspects of airborne contamination caused by the use of dental handpieces in the operative environment. Journal of the American Dental Association, 151(9), 660-667.

[11] Munster, V. J., Koopmans, M. van Doremalen, N. van Riel, D. $\&$ de Wit, E. 2020. A novel coronavirus emerging in Chinakey questions for impact assessment. N. Engl. J. Med., vol. 382, no. 8, pp. 692-694. DOI: 10.1056/NEJMp2000929

[12] PressAcademia, 2018. Definition of Case Study. Retrieved from https://www.pressacademia.org/definition-of-case-study/

[13] Starman, A., B. 2013. The case study as a type of qualitative research. Journal of Contemporary · Educational Studies, 64 (130), 28-43.

[14]Turnbull, D., Chugh, R., \& Luck, J. 2019. Learning management systems: An overview. In A. Tatnall (Ed.), Encyclopedia of Education and Information Technologies. Cham, Switzerland: Springer Nature. https://doi.org/10.1007/978-3-319-60013-0_248-1. 